Arab World English Journal (AWEJ) Volume 12. Number1 March 2021

DOI: https://dx.doi.org/10.24093/awej/vol12no1.8

Pp. $113-127$

\title{
The Effect of Explicit Instruction of Requests on Saudi EFL learners using a pre-test, post-test Approach
}

\author{
Israa A Qari \\ English Language Institute \\ King Abdulaziz University \\ Jeddah, Saudi Arabia \\ Email: iaqari@kau.edu.sa
}

Received: 9/28/2020

Acceoted: 2/1/2021

Published: $3 / 24 / 2021$

\begin{abstract}
The aim of the current study is to test whether explicit instruction of various L2 request forms can be a useful measure in developing Saudi learners' linguistic and pragmatic competences. This study is based on the results obtained from a previous research investigating interlanguage requests. The findings in that study suggested that the second language learners were not aware of some of the request strategies which were exclusively employed by the British English native speakers. The aim and the question of this study is to find out whether explicit instruction of request strategies will be effective in helping Saudi EFL learners gain linguistic knowledge and achieve pragmatic appropriateness in making requests in L2. Thirty female foundation year students participated in this study. They were all EFL learners studying at King Abdul Aziz University in Jeddah, Saudi Arabia. The group underwent three phases of instruction: pre-test, instruction/intervention, and post-test. The first and last phases consisted of written questionnaires which were distributed right before and after the instruction phase. The results showed that in the third phase, the students demonstrated great progress in their understanding of request forms in L2. Their improvement was manifested by the learners' acknowledgement of these forms as proper employment of request strategies in English, recognition of request function names, ability to assign correct functions to linguistic realizations and their overall understanding of the appropriate use of these forms dictated by the weightiness of different request situations.

Keywords: explicit instruction, implicit instruction, metapragmatic information, pre-test post-test requests, Saudi EFL learners, requests, speech acts
\end{abstract}

Cite as: Qari, I. A . (2021). The Effect of Explicit Instruction of Requests on Saudi EFL learners using a pre-test, post-test Approach. Arab World English Journal, 12 (1) 113-127.

DOI: https://dx.doi.org/10.24093/awej/vol12no1.8 
Arab World English Journal (AWEJ) Volume 12. Number 1. March 2021

The Effect of Explicit Instruction of Requests on Saudi EFL learners

Qari

\section{Introduction}

Recently, linguists have been attempting to make a shift in second language teaching methodology from a mere focus on sequential coverage of grammatical structures of the target language (linguistic competence) to the inclusion of teaching appropriate rules of L2 communication (pragmatic competence). One of the most essential components of pragmatic competence is illocutionary competence, that is, "knowledge of speech acts and speech functions" (Eslami-Rasekh, 2005, p. 200). Rueda (2006) holds the view that "pragmatic ability can be systematically developed through planned classroom activities" (p. 170). Rajabia, Azizifara, and Gowhary (2015) stress that teaching speech acts gives EFL students the opportunity to "become acquainted with sociolinguistic conventions of language use and cultural differences which form proper use in English as opposed to their first sociolinguistic system" (p. 233).

The positive correlation between pragmatic instruction and learners' pragmatic development has already been established in the field of interlanguage research literature (for a complete review, see Plonsky \& Zhuang, 2019). However, in practice, L2 explicit pragmatic instruction (providing metapragmatic information to the students) is seldom included as a component of teachers' classroom lesson plans (Gu, 2011; Thomas, 1983; Vellenga, 2004). Reasons include difficulty of pragmatic teaching in terms of available resources and lack of sufficient pragmatic information in the textbooks. This is the main problem for which this study is attempting to find a solution. If the outcome of the explicit instruction of requests to Saudi students proves useful, this might suggest the necessity of incorporating teacher-led consciousness-raising and pragmatic-awareness activities in EFL classrooms.

In the context of the Saudi EFL learning system, Al-Asmari (2015) gathered evaluative data from 100 male and female teachers teaching EFL at Taif University in Saudi Arabia. The purpose of the study was to investigate the challenges hindering a proper implementation of teaching pragmatics to EFL learners. The results showed that the main reasons confronting the teachers were lack of teacher training in the Saudi education system, problems in accessing resources, lowproficiency of students, lack of student motivation, difficulty of obtaining a concrete description of what teaching pragmatics entails, and finally and most importantly, the university's main focus on exams and exam scores rather than the actual learning of the students. As an EFL teacher at a Saudi university myself, $I$ it can be concurred that the obstacles Al-Asmari mentioned are struggles that my colleagues and I face daily in our Saudi EFL classrooms.

Batawi (2006) suggests that "in the long run, Saudi teachers should establish their own research in order to develop language teaching methods that are more suitable to the Saudi context" (p. 4). Based on this observation, a speech act study was conducted to attain empirical data about Saudi EFL students' pragmatic abilities and limitations. English request forms produced by British English Native speakers (BENs) were compared with requests made by Saudi English as Foreign Language Learners (SEFLLs). The two groups responded to a written Discourse Completion Test (DCT) questionnaire where they were asked to make a request to the hearer $(\mathrm{H})$ in eight socially different situations. It was hoped that this research-based approach would provide me with evidence for particular problems arising in my classroom and ways to improve my pragmatic teaching skills in a professional manner.

Arab World English Journal 
Among the reasons requests were chosen in this study was that according to $\mathrm{Gu}$ (2011) "request is one of the most difficult speech acts to be acquired" (p. 105) since they are "facethreatening, and therefore call for considerable linguistic expertise on the part of the learner [and] differ cross- linguistically" (Ellis, 1994, p.168). "Requests are [also] particularly interesting because they are speech acts that learners cannot avoid making in the target language (...) and which learners are also exposed to on a regular basis" (Qari, 2017, p.82). Furthermore, requests are acts in which social relationships can be challenged as requesting the $\mathrm{H}$ to do something to benefit the speaker (S) requires the $\mathrm{S}$ to observe a number of social factors. These include the participants' social statuses and distances, as well as imposition, obligation, and right. Requests also vary from culture to culture; therefore, they can be a rich source of information about the sociocultural rules embedded in different speech communities.

The data results of my study demonstrated that there was a total of 15 request forms which were employed only by the BENs and had zero incidence in the SEFLLs request productions. Not only will these forms have to be individually taught to the SEFLLs, their appropriate use according to the request contexts will need to be instructed as well. In other words, both linguistic and pragmatic understanding and use of English requests will have to be promoted inside SEFLL educational settings. According to El-Dakhs (2019, p. 297), "developing pragmatic competence is becoming a requirement for Saudi learners of English to advance a successful career, especially when most well-paying jobs require work in multi-cultural contexts where English is the main language for communication" (as cited in Alsmari, 2020, p. 5). As I am in agreement with El-Dakhs, I conducted the current study for my own EFL class. Consent forms were sent out and thirty out of the thirty five students in my class agreed to participate in this study. No extra credit of any kind was offered nor rewarded for participation.

Framed in Austin's (1975) and Searle's (1969) theory of speech acts, the present study looked into the effect of explicit pragmatic teaching on SEFLLs' production and reception of L2 requests. Pre-test and post-test questionnaires were distributed to the students, right before and after the instruction phase, hoping to address the following research question (RQ):

RQ1: Will explicitly teaching SEFLLs request strategies help the students learn the names of these strategies?

RQ2: Will explicitly teaching SEFLLs request strategies help the students learn these strategies and their specific functions?

\section{Literature Review}

Recently, explicit instruction of requests to EFL learners for the purpose of improving their pragmatic competences has attracted some attention within the interlanguage field of linguistic research (Anani Sarab \& Alikhani, 2015; Shokouhi, 2016; Gu, 2011). However, in the Saudi EFL context, most research studies seem to give more focus on investigating the linguistic strategies used in the production of the request speech act (e.g. Al-Otaibi, 2015; Tawalbeh \& Al-Oqaily, 2012) than concentrating on its continued pragmatic development. Furthermore, there is a dearth of research concerning the influence of introducing pragmatic instruction in the EFL classroom. Saudi research studies that examined the effect of teaching pragmatic aspects of requests on SEFLLs' pragmatic development could not be found. This justifies the need for this study and identifies a gap in the 
Arab World English Journal (AWEJ) Volume 12. Number 1. March 2021

The Effect of Explicit Instruction of Requests on Saudi EFL learners

Qari

field. Subsequently, the literature review of studies involving Saudi learners will have to have a broader scope and include investigations of speech acts in addition to requests. It will also touch upon a variety of related topics such as the various factors, other than instruction, that are thought to have an impact on learners' acquisition and development of L2 pragmatic competence. These include individual levels of language proficiency and length of residence in a target language country.

The influence of increased language proficiency on L2 pragmatic competence has somewhat triggered some interest. Alkahtani (2012) and El-Dakhs (2018) compared speech acts as produced by Saudi high and low level learners. Alkahtani's (2012) investigation showed that there were minor insignificant differences between the high level and low level groups in terms of their request strategies, while El-Dakhs' (2018) study pointed out effective and frequent native-like use of speech acts in favor of the high level Saudi learners. However, both studies agreed that in some instances both SEFLL groups deviated from the English native speakers, for example in their post-head request selections. This gives support to the traditional definition of interlanguage being a "system in its own right" (Selinker, 2014, p. 230) where the learners produce language which can "include features of L1/L2 as well as some of the learner's creative innovations" (El-Dakhs, 2018, p. 614).

In order to determine the role of residence in countries with English as a first official language on learners' pragmatic awareness, some researchers target population who are residents in English speaking countries and thus learn English as a second language (ESL). Two apology studies were among this body of research, Al-Ghamdi (2013) and Alhudhaif (2000). These studies targeted Saudi ESL students who were pursuing their higher education in the United States. The collective results of these examinations highlighted the positive correlation of prolonged stay in a target community with higher L2 pragmatic competence and lower levels of L1 pragmatic transfer. Nevertheless, it was shown that in some instances, even long term residents in English speaking countries had some cultural influences from L1's apologetic behavior. For instance, a few participants were reported to address the offended party with terms borrowed directly from Arabic, e.g. 'sorry sister' addressed to a female stranger and 'I apologize auntie' to an elderly lady for abruptly bumping into her on the street.

Of more relevance to the current paper, a few research studies examined the effectiveness of various types of teaching methods on SEFLLs' L2 acquisition and development. For example, in his research, Fattah (2018) recruited 32 fifth level SEFLLs studying English in Qassim Private Colleges (QPC) in Saudi Arabia. He compared his students' understanding of semantic and pragmatic notions of L2 before implementing role plays and after. He concluded that role plays were able to develop the SEFLLs' semantic and pragmatic competences, showing statistical differences between the students' results before and after role play intervention.

Al-Kharrat (2000) examined ways to teach SEFLLs how adding "-ing" to an English word consisting of one syllable can change its spelling. The researcher administered two lessons made for the 30 participants, pre-prepared with the implementation of deductive (general to specific) and inductive (specific to general) teaching methods. He recommended the adoption of both methods in the classroom; however, he was in particular favor of the employment of the inductive technique as it was found to be highly engaging and mentally challenging for the students. 
Arab World English Journal (AWEJ) Volume 12. Number 1. March 2021

The Effect of Explicit Instruction of Requests on Saudi EFL learners

Qari

Exploring the teachability of the acquisition of structural discourse markers, Alraddadi (2019) enlisted 49 female SEFLLs, divided them into groups and exposed them to three types of teaching styles: task-based, inductive and deductive. The findings demonstrated that although all three types yielded improved results in terms of L2 development, the group which received the inductive approach outperformed the other two groups. Consequently, the researcher suggested that it could be possible that the inductive approach can have greater effect on the learners' acquisition and development than the other two methods.

Alsmari (2020) set out her research to establish the effect of metapragmatic instruction of the speech act of complaint on SEFLLs through the implementation of video-driven prompts. The results of the post-intervention treatment demonstrated significant improvement on SEFLLs' pragmalinguistic and sociopragmatic skills in the production of English complaints.

Employing a pre-test/post-test design, Rajabia et al. (2015) attempted to examine the impact of explicit metapragmatic instruction on learners' comprehension of requests. Through thorough statistical analysis, findings revealed that Iranian EFL learners' pragmatic knowledge of requests developed significantly post the instruction phase. It thus maintains the advantages of incorporating direct pragmatic instruction in EFL classrooms to foster learners' pragmatic awareness. Similar findings were documented in related research studies (Farahian, Rezaee, \& Gholami, 2012; Khodareza \& Lotfi, 2013; Rafieyan et al., 2014). Collectively, the results indicated that students experienced significant increase in their pragmatic skills post the instruction phase, concluding that pragmatics is not effectively acquired without explicit direct instruction/intervention, which helps the learners process material on a conscious level. This conclusion gives support to Schmidt's (1990, 2001) 'noticing' theory in which he advocates that "input does not become intake for language learning unless it is noticed, that is, consciously registered" (Schmidt, 2012, p. 1).

The current study is closely related to the aforementioned research directions. However, its main focus is to examine the extent to which explicit instruction of various request forms can have on the pragmatic development of SEFLLs' L2 requests. To the best of my knowledge, this study has not been done before in the Saudi EFL context. Hopefully, this research will fill in an important gap and contribute to the existing body of literature involving SEFLLs in pragmatics, speech act and classroom-based research.

\section{Methods}

\section{Participants}

This study is conducted with the participation of 30 Saudi females currently in their foundation/preparatory year at King Abdulaziz University (KAU) in Jeddah, Saudi Arabia. The participants were systematically selected from level four English, which is the highest course level a student can reach at KAU foundation year. Their ages ranged between 18-25. The data was collected during the month of September 2020. The English Language Institute at KAU runs its preparatory year program courses to provide intensive instruction of English to its students in order to enhance their English language skills and facilitate their college entry. These courses are delivered by qualified teachers who are mostly also Saudi nationals. The program consists of four modules, lasting seven weeks each, and four levels of English proficiency, level one being the most basic and level four the most advanced. In each module, a textbook and workbook are used following a 
Arab World English Journal (AWEJ) Volume 12. Number 1. March 2021

The Effect of Explicit Instruction of Requests on Saudi EFL learners

Qari

specified weekly pacing guide. Ahead of enrolment, students are placed into their suitable levels according to their achievement in the Oxford Placement Test designed by University of Oxford. After completion of a module, students are promoted to a higher level until they successfully complete level four.

\section{Research Instruments}

The main data collection method used in this study is written questionnaires. Two questionnaires were used; one was distributed pre-instruction and the other was given post-instruction. The preinstruction questionnaire was in a (Yes/No) form and requested the students to identify the formations which they thought were correct uses of requests in English. This step was done to inform the researcher about the students' baseline knowledge and understanding of appropriate target-like requests in English, for further comparison with the post-test. The students had to fill in the same questionnaire again post-instruction. Moreover, they were asked to identify the request functions (e.g. willing. ability, permission, etc.) used for each request form. The 15 request forms, previously employed only by the BENs, were introduced in the pre-test questionnaires. The SEFLLs were supposed to check all of them off as correct in the form of a 'yes' answer.

\section{Table 1. A script of the pre-instruction questionnaire, distributed again after treatment phase}

Have a look at the following forms and decide which ones are correct uses of requests in English by native speakers. Please choose yes or no:

1- Would I be able to come to the party with you tomorrow? (yes/no)

2- Would it be possible to come to the party with you tomorrow? (yes/no)

3- Would it be OK if I came to the party with you tomorrow? (yes/no)

4- Would it be OK if I could come to the party with you tomorrow? (yes/no)

5- Can you let me know if it would be possible to come to the party with you tomorrow? (yes/no)

6 - Is there a chance I could come to the party with you tomorrow? (yes/no)

7- Is there any way I would be able to come to the party with you tomorrow? (yes/no)

8- Have you got a dress I could borrow for the party tomorrow? (yes/no)

9- Is it OK if I could come to the party with you tomorrow? (yes/no)

10- Do you think I could come to the party with you tomorrow? (yes/no)

11- Do you think it would be possible if I could come to the party tomorrow? (yes/no)

12- I wonder whether I could come with you to the party tomorrow. (yes/no)

13- I am wondering if it's alright that I come with you to the party tomorrow. (yes/no)

14- I don't suppose I could come to the party tomorrow. (yes/no)

15- You couldn't take me to the party with you tomorrow, could you? (yes/no)

After submitting their answers for the pre-instruction questionnaire, the learners attended an online seminar with the researcher in which there was a discussion about their questionnaire results. Consequently, the learners were instructed with various valid request structures in English. They were also given details about how to individually categorize request sequences based on their functions, as demonstrated in Table two below. Color codes were used to distinguish between various request functions. A color was assigned to each request function along with its corresponding linguistic realization(s) so that learners can identify and match them quite easily. The categories are modified versions of the request query preparatory conditions (e.g. ability, willing, possibility). introduced by Blum-Kulka and Olshtain in their famous 1984 CCSARP project.

Arab World English Journal 
Arab World English Journal (AWEJ) Volume 12. Number 1. March 2021

The Effect of Explicit Instruction of Requests on Saudi EFL learners

Qari

Table 2. A list of the request functions and their linguistic realizations

\begin{tabular}{|c|c|}
\hline Function & Linguistic realization(s) \\
\hline Willing & will/would \\
\hline Ability & can/could/able to \\
\hline Possibility & possible/any chance/any way \\
\hline Permission & OK/ alright/let me/mind \\
\hline Possession & do you have/have you got \\
\hline Consultation & do you think/reckon \\
\hline Wondering & wonder/wondering \\
\hline Negative & no/don't/couldn't/can't/not \\
\hline Supposition & suppose \\
\hline Tag. Question & example: could you? \\
\hline
\end{tabular}

After instructing the SEFLLs with the request functions and their corresponding linguistic realizations, they were further taught that some request functions can be used singularly (e.g. Would you help me?) [willing], or in tandem with other conditions (e.g. Would you be able to help $m e$ ?) [willing. ability]. Below is an example of the 'willing' request function being used singularly and along with other request functions as follows:

Willing: will/would

- Used in a singular condition request form: (willing) Will you...? Would you...?

- Used in a double condition request form: (willing/permission) Would you mind...?

- Used in a triple condition request form: (willing/permission/ability) Would it be ok if I could...?

- Used in a quadruple condition request form: (ability/permission/willing/possibility) Can you let me know if it would be possible to...?

Next, the SEFLLs were given linguistic examples of various appropriate request structures in English (see Table three) following the sequence of the functions for each request form strategy. They were also taught how to create and provide functional analysis of requests through identifying the conditions used per strategy and their sequential pattern as they appear in each request form.

Table 3. The fifteen request forms taught to the SEFLLs during the study's instructional phase

\begin{tabular}{|l|l|}
\hline Name of request form strategy & Linguistic examples for each request form strategy \\
\hline 1.Willing.ability: & Would you be able to....? Would I be able to...? \\
\hline 2.Willing.possibility: & Would it be possible to...? \\
\hline 3.Willing.permission: & Would it be ok if I...? Would it be ok if you...? \\
\hline 4.Willing.permission.ability: & Would it be ok if I could...? \\
\hline 5.Ability.permission.willing.possibility: & Can you let me know if it would be possible to...? \\
\hline 6.Possibility.ability: & Is there any chance I could...? Is there any way I could...? \\
\hline 7.Possibility.willing.ability: & Is there any way I would be able to...? \\
\hline 8.Possession.ability: & $\begin{array}{l}\text { Do you have [a pen] I could [borrow]? Have you got [any } \\
\text { money] I could use? }\end{array}$ \\
\hline 9.Permission.ability: & Is it be ok if I could...? \\
\hline 10.Consultation.ability: & Do you think you could...? \\
\hline 11.Consultation.willing.possibility.ability: & Do you think it would be possible if I could...? \\
\hline \hline
\end{tabular}

Arab World English Journal 
Arab World English Journal (AWEJ) Volume 12. Number 1. March 2021

The Effect of Explicit Instruction of Requests on Saudi EFL learners

Qari

\begin{tabular}{|l|l|}
\hline 12.Wondering.ability: & $\begin{array}{l}\text { I was wondering if I could...? I wonder whether you } \\
\text { could...? }\end{array}$ \\
\hline 13.Wondering.permission: & I am wondering if it's alright that...? \\
\hline 14.Negative.supposition.ability: & Don't suppose I could [have a quick look at your notes]? \\
\hline 15.Negative.ability.tag.question: & You couldn't [lend me a hundy], could you? \\
\hline
\end{tabular}

Finally, the researcher attempted to raise the SEFLLs' pragmatic awareness through elaborating on the metapragmatic aspects of the request formulas, including the critical sociopragmatic elements associated with appropriate use of these request strategies regarding social power, distance, and level of imposition. Upon ending the seminar, the learners were asked to fill in the post-instruction questionnaires in order to assess the effectiveness of the treatment. Furthermore, they were asked to mark the functions (willing, ability, permission... etc.) present in each request strategy. The purpose of this exercise was to assess the SEFLLs' understanding of the structure of the request sets that they had been taught and the sequence of the functions present in each request.

\section{Results and Analysis}

This study was set out to examine the impact of explicit instruction of request structures on the enhancement of SEFLLs' pragmatic understanding of English requests. 30 female SEFLLs took part in this research. During the initial pre-instruction phase, the SEFLLs were provided with various linguistically correct and pragmatically appropriate request forms, used previously by native English speakers. The participants were supposed to acknowledge the accurateness of these forms and check all of them off as 'correct' in the form of a 'yes' answer. (See Table four).

Table 4. The difference in number and percentage of the participants' data pre- and post-test

\begin{tabular}{|l|r|r|r|r|r|r|r|r|r|r|}
\hline \multirow{2}{*}{ Name of request form strategy } & \multicolumn{4}{|c|}{ Pre-test } & \multicolumn{4}{c|}{ Post-test } & \multicolumn{2}{c|}{ Increase } \\
\cline { 2 - 12 } & \multicolumn{2}{|c|}{ Yes } & \multicolumn{2}{|c|}{ No } & \multicolumn{2}{c|}{ Yes } \\
\cline { 2 - 12 } & No. & $\%$ & No. & $\%$ & No. & $\%$ & No. & $\%$ & No. & $\%$ \\
\hline 1.Willing.ability & 23 & 76.7 & 7 & 23.3 & 30 & 100 & 0 & 0 & 7 & 23.3 \\
\hline 2.Willing.possibility & 23 & 76.7 & 7 & 23.3 & 30 & 100 & 0 & 0 & 7 & 23.3 \\
\hline 3.Willing.permission & 17 & 56.7 & 13 & 43.3 & 30 & 100 & 0 & 0 & 13 & 43.3 \\
\hline 4.Willing.permission.ability & 24 & 80 & 8 & 20 & 30 & 100 & 0 & 0 & 8 & 20 \\
\hline $\begin{array}{l}\text { 5.Ability.permission. } \\
\text { willing.possibility }\end{array}$ & 19 & 63.3 & 11 & 36.7 & 30 & 100 & 0 & 0 & 11 & 36.7 \\
\hline 6.Possibility.ability & 28 & 93.3 & 2 & 6.7 & 30 & 100 & 0 & 0 & 2 & 6.7 \\
\hline 7.Possibility.willing.ability & 24 & 80 & 8 & 20 & 30 & 100 & 0 & 0 & 8 & 20 \\
\hline 8.Possession.ability & 26 & 86.7 & 4 & 13.3 & 30 & 100 & 0 & 0 & 4 & 13.3 \\
\hline 9.Permission.ability & 23 & 76.7 & 7 & 23.3 & 30 & 100 & 0 & 0 & 7 & 23.3 \\
\hline 10.Consultation.ability & 25 & 83.3 & 5 & 16.7 & 30 & 100 & 0 & 0 & 5 & 16.7 \\
\hline $\begin{array}{l}\text { 11.Consultation.willing. } \\
\text { possibility.ability }\end{array}$ & 17 & 56.7 & 13 & 43.3 & 30 & 100 & 0 & 0 & 13 & 43.3 \\
\hline 12.Wondering.ability & 28 & 93.3 & 2 & 6.7 & 30 & 100 & 0 & 0 & 2 & 6.7 \\
\hline
\end{tabular}

Arab World English Journal 
Arab World English Journal (AWEJ) Volume 12. Number 1. March 2021

The Effect of Explicit Instruction of Requests on Saudi EFL learners

Qari

\begin{tabular}{|l|r|r|r|r|r|r|r|r|r|r|}
\hline 13.Wondering.permission & 18 & 60 & 12 & 40 & 30 & 100 & 0 & 0 & 12 & 40 \\
\hline 14.Negative.supposition.ability & 19 & 63.3 & 11 & 36.7 & 30 & 100 & 0 & 0 & 11 & 36.7 \\
\hline 15.Negative.ability.tag.question & 28 & 93.3 & 2 & 6.7 & 30 & 100 & 0 & 0 & 2 & 6.7 \\
\hline
\end{tabular}

According to Table four pre-test data results, it was observed that the SEFLLs seemed to suffer from linguistic weaknesses and pragmatic deficiencies in their knowledge of the full extent of the possible forms available to realize requests in English. Succeeding instruction, however, there was a substantial increase in the SEFLLs' scores as all thirty students identified the fifteen forms as correct request strategies in English. This goes to show that the pedagogical intervention might have had an overall positive effect on the pragmatic development of the SEFLLs' L2 requests after being enrolled in the teaching experiment.

On closer inspection of the pre-test results, it was noticed that the SEFLLs specifically struggled to acknowledge the validity of quadruple function request strategies (QFRSs) (e.g. request strategies five and eleven). They also appeared to have a limited understanding of some of the request strategies which contained the 'permission' function (as in strategies three and thirteen). Moreover, in request strategy fourteen, they seemed quite novice to the notion of 'negative supposition' in making requests.

Following discussing these points with the students, the researcher was told that in all their years of EFL formal education, they had never been taught most of these requests before, particularly request strategy fourteen. They further complained that their English textbooks primarily focused on short affirmative common request strategies, none of which contained combined functions or negative supposition.

One final note concerning Table four is that in the pre-test data, out of thirty students, twenty seven were unable to recognize and validate all the fifteen request forms, and only three correctly verified the appropriateness of every request strategy. However, it is possible that even these three students ticked a random 'yes' to all the strategies just to be done with filling in the questionnaire quickly. It is highly unlikely that they had true previous knowledge of every request strategy present in the pre-test questionnaire. On the other hand, in the post-test results, it was shown that the thirty participants were aware of the new request forms they had just been taught, as they were able to verify and recognize them immediately after the intervention. This time it appears that the SEFLLs had better knowledge about forming different request strategies in L2 and the function sequences present in this study.

Table 5. The number of uses per each request function (out of 30 students) on post-test

\begin{tabular}{|l|r|r|r|r|r|c|c|c|c|c|}
\hline \multirow{2}{*}{ Name of request form strategy $\downarrow$} & \multicolumn{9}{|c|}{ The number of uses per each request function (out of 30 students) } \\
\cline { 2 - 14 } & Wil & Ab & Pb & Per & Ps & Con & Won & Neg & -Sup & TQ \\
\hline 1.Willing.ability & $\mathbf{1 9}$ & $\mathbf{9}$ & 3 & 4 & 0 & 2 & 1 & 2 & 1 & 0 \\
\hline 2.Willing.possibility & $\mathbf{1 6}$ & 1 & $\mathbf{2 1}$ & 2 & 0 & 2 & 3 & 0 & 2 & 1 \\
\hline 3.Willing.permission & $\mathbf{1 5}$ & 3 & 3 & $\mathbf{1 2}$ & 1 & 2 & 0 & 0 & 1 & 1 \\
\hline 4.Willing.permission.ability & $\mathbf{1 3}$ & $\mathbf{1 6}$ & 4 & $\mathbf{9}$ & 2 & 2 & 0 & 0 & 1 & 1 \\
\hline $\begin{array}{l}\text { 5.Ability.permission. } \\
\text { willing.possibility }\end{array}$ & $\mathbf{1 3}$ & $\mathbf{1 2}$ & $\mathbf{1 2}$ & $\mathbf{1 2}$ & 8 & 4 & 0 & 5 & 1 & 0 \\
\hline
\end{tabular}

Arab World English Journal 
Arab World English Journal (AWEJ) Volume 12. Number 1. March 2021

The Effect of Explicit Instruction of Requests on Saudi EFL learners

Qari

\begin{tabular}{|l|c|c|c|c|c|c|c|c|c|c|}
\hline 6.Possibility.ability & 2 & $\mathbf{1 3}$ & $\mathbf{1 3}$ & 6 & 4 & 3 & 1 & 1 & 2 & 1 \\
\hline 7.Possibility.willing.ability & $\mathbf{1 5}$ & $\mathbf{1 0}$ & $\mathbf{1 2}$ & 3 & 4 & 4 & 1 & 0 & 3 & 1 \\
\hline 8.Possession.ability & 3 & $\mathbf{1 5}$ & 2 & 3 & $\mathbf{1 3}$ & 3 & 2 & 4 & 0 & 2 \\
\hline 9.Permission.ability & 4 & $\mathbf{1 0}$ & 2 & $\mathbf{1 3}$ & 3 & 1 & 2 & 1 & 3 & 3 \\
\hline 10.Consultation.ability & 7 & $\mathbf{1 0}$ & 2 & 1 & 2 & $\mathbf{1 3}$ & 1 & 2 & 2 & 3 \\
\hline $\begin{array}{l}\text { 11.Consultation.willing. } \\
\text { possibility.ability }\end{array}$ & $\mathbf{2 2}$ & $\mathbf{1 2}$ & 9 & 2 & $\mathbf{1 3}$ & $\mathbf{1 0}$ & 5 & 0 & 2 & 0 \\
\hline 12.Wondering.ability & 4 & $\mathbf{1 0}$ & 2 & 1 & 3 & 1 & $\mathbf{1 5}$ & 1 & 1 & 2 \\
\hline 13.Wondering.permission & 4 & $\mathbf{1}$ & 4 & $\mathbf{1 0}$ & 1 & 3 & $\mathbf{1 2}$ & 4 & 1 & 1 \\
\hline 14.Negative.supposition.ability & 3 & $\mathbf{1 0}$ & 3 & 6 & 0 & 4 & 1 & $\mathbf{1 2}$ & $\mathbf{6}$ & 1 \\
\hline 15.Negative.ability.tag.question & 3 & $\mathbf{1 0}$ & 2 & 7 & 3 & 5 & 4 & $\mathbf{9}$ & 0 & $\mathbf{4}$ \\
\hline
\end{tabular}

*List of Table five contractions:

Willing $=$ Wil

Ability $=\mathrm{Ab}$

Possibility $=\mathrm{Pb}$

Permission $=$ Per

Possession $=$ Ps

Consultation $=$ Con

Wondering $=$ Won

Negative $=$ Neg

Supposition $=$ Sup

Tag.question $=$ TQ

Table 6. The percentage of uses per each request function (out of 100\%) on post-test

\begin{tabular}{|l|c|c|c|c|c|c|c|c|c|c|c|}
\hline \multirow{2}{*}{$\begin{array}{l}\text { Name of request form strategy } \\
\downarrow\end{array}$} & \multicolumn{7}{|c|}{ The percentage of uses per each request function (out of 100\%) } \\
\cline { 2 - 12 } & Wil & Ab & Pb & Per & Ps & Con & Won & Neg & -Sup & TQ \\
\hline 1.Willing.ability & $65 \%$ & $30 \%$ & - & - & - & - & - & - & - & - \\
\hline 2.Willing.possibility & $55 \%$ & - & $70 \%$ & - & - & - & - & - & - & - \\
\hline 3.Willing.permission & $50 \%$ & - & - & $40 \%$ & - & - & - & - & - & - \\
\hline 4.Willing.permission.ability & $45 \%$ & $55 \%$ & - & $30 \%$ & - & - & - & - & - & - \\
\hline $\begin{array}{l}\text { 5.Ability.permission. } \\
\text { willing.possibility }\end{array}$ & $45 \%$ & $40 \%$ & $40 \%$ & $40 \%$ & - & - & - & - & - & - \\
\hline 6.Possibility.ability & - & $50 \%$ & - & - & $45 \%$ & - & - & - & - & - \\
\hline 7.Possibility.willing.ability & $50 \%$ & $35 \%$ & $40 \%$ & - & - & - & - & - & - & - \\
\hline 8.Possession.ability & - & $50 \%$ & - & - & $10 \%$ & - & - & - & - & - \\
\hline 9.Permission.ability & - & $35 \%$ & - & $45 \%$ & - & - & - & - & - & - \\
\hline 10.Consultation.ability & - & $35 \%$ & - & - & - & $45 \%$ & - & - & - & - \\
\hline $\begin{array}{l}\text { 11.Consultation.willing. } \\
\text { possibility.ability }\end{array}$ & $75 \%$ & $40 \%$ & - & - & $45 \%$ & $35 \%$ & - & - & - & - \\
\hline 12.Wondering.ability & - & $35 \%$ & - & - & - & - & $50 \%$ & - & - & - \\
\hline 13.Wondering.permission & - & - & - & $35 \%$ & - & - & $40 \%$ & - & - & - \\
\hline 14.Negative.supposition.ability & - & $35 \%$ & - & - & - & - & - & $40 \%$ & $20 \%$ & - \\
\hline 15.Negative.ability.tag.question & - & $35 \%$ & - & - & - & - & - & $30 \%$ & - & $15 \%$ \\
\hline
\end{tabular}

Arab World English Journal 
Based on Table 5 and Table 6 post-instruction data results, a number of generalizations can be derived. First, the overall majority of the SEFLLs picked the correct corresponding functions (highlighted in bold) for each request strategy; the rest of the functions (not in bold) had considerably lower incidence rates. Second, in terms of correct selections, eight strategies out of ten were appropriately chosen by nine or more of the SEFLLs, whereas only two strategies (namely Sup and TQ) were chosen by a lesser number of students; six and four SEFLLs to be exact. Third, there was a high incidence rate of incorrect selections made in request strategies which consisted of QFRSs (strategies five and eleven), where eight and nine students respectively chose nonconstituent functions. Fourth, the function 'permission' was wrongly chosen at a high rate $(20 \%$ or more) by the SEFLLs in request strategies where it is also a non-constituent, such as in strategies six, fourteen, and fifteen. Fifth, the requests which the SEFLLs seemed to find particularly difficult were strategies that consisted of these functions: QFRSs, negative supposition, tag questions, and permission. Sixth and last, it can be concluded from the post-instruction results that the single teaching session the SEFLLs underwent was able to develop their L2 requests both strategically and functionally; albeit their strategy recognition seemed to surpass their functional analysis abilities.

\section{Discussion}

This study was set out to examine the extent at which explicit instruction of request forms can have on the pragmatic and linguistic developments of SEFLLs' L2 requests. The research questions will be stated again here for the sake of convenience:

RQ1: Will explicitly teaching SEFLLs request strategies help the students learn the names of these strategies?

RQ2: Will explicitly teaching SEFLLs request strategies help the students learn these strategies and their specific functions?

Through the research data results, it is evident that explicit instruction of L2 requests facilitated learners' interlanguage pragmatics development. By implementing direct explicit instruction of the speech act, the students were able to reassess and add to their previous knowledge of requests. They were also able to categorize requests based on their functions demonstrating advanced and improved pragmatic abilities.

On closer examination, the RQ makes a distinction between learning request forms (structural development) and request functions (functional analysis). In regards to learning new request forms, the SEFLLs' responses in the post-test showed that they had successfully learned a wider range of L2 request structures in comparison with the limited accurate answers they gave in the pre-test questionnaires. In terms of learning request functions, the SEFLLs further demonstrated strengthened abilities in correctly pinpointing most of the functions present in the request strategies.

However, it is crucial to note that the SEFLLs seemed to have encountered some difficulties in identifying strategies which consisted of the following functions: QFRSs, negative supposition, tag questions, and permission. The SEFLLs admitted that they had never come across these functions in their EFL textbooks before. It can thus be proposed that explicit direct instruction of L2 speech acts can possibly facilitate EFL learners' acquirement of new speech act strategies and functions on the pretext that acquiring the former might be faster than the latter. Derived from the above is the possible conclusion that linguistic realizations of whole request strategies might be easier to acquire than linguistic realizations of individual request functions. 
Arab World English Journal (AWEJ) Volume 12. Number 1. March 2021

The Effect of Explicit Instruction of Requests on Saudi EFL learners

Qari

In regards to assessment of the methodology, the post-test data results provided further evidence for pedagogical intervention being an effective tool in enhancing EFL learners' pragmatic and speech act abilities and is consistent with previous interlanguage research studies (EslamiRasekh et al., 2004; Kerber, 2020; Nguyen, Pham, \& Pham, 2012).

Furthermore, the teachability of pragmatic aspects of L2 through applying a 'pre-test/posttest' design is aligned with results from the following research (Alsuhaibani, 2020; Halenko \& Jones, 2011; Khodareza \& Lotfi, 2013; Rajabia et al. 2015, Shark, 2019; Yilmaz \& Koc, 2020), in which learners were reported to have performed better in the post-test after the instruction phase. In addition, explicit instruction of requests to EFL learners was shown to be an effective tool in improving the students' pragmalinguistic and sociopragmatic skills as was role play intervention (Fattah, 2018) and video-driven intervention in Alsmari's (2020) study of learner complaints.

Similar findings were documented in related research studies (Farahian et al., 2012; Khodareza \& Lotfi, 2013; Rafieyan et al., 2014). Collectively, the results indicated that students experienced significant increase in their pragmatic skills post the instruction phase, concluding that pragmatics is not effectively acquired without explicit direct instruction/intervention, which helps the learners process material on a conscious level. This conclusion gives support to Schmidt's (1990, 2001) 'noticing' theory in which he advocates that "input does not become intake for language learning unless it is noticed, that is, consciously registered" (Schmidt, 2012, p. 1).

Based on the study's post-test data, the researcher recommends the adoption of both explicit (providing rules), as well as inductive (drawing from linguistic examples) designs of teaching when instructing pragmatic aspects of requests to EFL students. Employing inductive methods, as opposed to deductive methods, showed better results in interventional studies which compared between the two types of instruction (Al-Kharrat, 2000; Alraddadi, 2019). In fact, as Glaser (2014) asserts "in the wider area of SLA research, (...), studies investigating inductive and deductive instruction have found that inductively taught learners outperformed their deductively taught peers" (p. 154) Glaser further stipulates that "[it has been previously shown that] explicit-inductive designs were more beneficial than explicit-deductive ones" (ibid.). Therefore, implementing explicit-inductive means of teaching requests in the classroom can result in substantial improvements on the learners' understanding of requests' functions and uses.

An example of an explicit-inductive method of teaching requests can be manifested as follows: the teacher begins the lesson by inductively presenting new linguistic request examples to the students and later explicitly addresses the underlying rules pertaining to their appropriate uses and functions. This type of mixed explicit-inductive method of instruction can be very helpful where the instruction features activities during which the students actively engage in analyzing and discovering requests themselves, guided and helped, but not dominated, by the teacher.

Another finding surfaced from the data; it seems that the single instruction session the SEFLLs had was able to reinforce some of the previous knowledge they'd already had about forming requests in L2 but was not enough to establish completely novice request functions (e.g. QFRSs, Sup, TQ, and Per). The Students' lack of previous knowledge of the correct uses of these functions correlates with their inaccurate answers presented in request strategies that consisted of one of these 
functions. This conclusion provides considerable insight into the essential role of repetition to secure the new learning as a long-term memory (see Multiple-Trace Theory, Hintzman \& Block, 1971). In fact, one of the limitations of this study is that the teaching session was only provided once. Had there been more sessions given to the SEFLLs, their data might have generated more accurate results as repeated exposure to a stimulus increases its likelihood of being recalled. This suggests that, within EFL classrooms, new learning material must be repeated and reinforced over time for it to form subsequent memory pathways that are truly remembered and thoroughly understood by the students.

\section{Conclusion:}

Requesting is perhaps the most important speech act to teach because it is used often and in different situations; it also varies from language to language. This paper examined the impact of explicit instruction of request structures on developing SEFLLs' pragmatic understanding of English requests. Before the treatment intervention, the participants portrayed linguistic and pragmatic deficiencies in their understanding of English requests. When presented with some request forms previously produced by native speakers of English, most SEFLLs seemed completely unaware of them. Post-treatment intervention, however, there was a substantial improvement in the SEFLLs' knowledge of the new request strategies. This may add insight into the significance of explicit pedagogical intervention in teaching L2 speech acts, and the overall positive impact the teaching experience might have on the learners, even after a single session.

The SEFLLS complained that in their years of formal English education at school, they have never been taught rich request forms that vary linguistically or pragmatically. Their English textbooks usually stuck to short direct requests, with the overuse of the politeness marker 'please'. The learners mentioned that their frequent use of the request strategy (imperative + please) was probably due to the over-portrayal of this strategy in their English textbooks. It is therefore of utmost importance for English textbooks and EFL teachers to present different types of requests, which vary in their level of directness, so that learners can benefit from a larger and more diversified database of $\mathrm{L} 2$ request strategies.

\section{About the Author:}

Dr. Israa Qari is an assistant professor in Linguistics, currently teaching English in the ELI Preparatory year program, King Abdulaziz University, Jeddah, Saudi Arabia. She obtained her Doctorate degree from University of Roehampton, London, U.K. in 2017. She specializes in Cross-Cultural Linguistics and politeness research. https://orcid.org/0000-0003-3753-3655

\section{References}

Austin, J. L. (1975). How to do things with words (Vol. 88). Oxford, Oxford university press.

Al-Asmari, A. (2015). Communicative language teaching in EFL university context: Challenges for teachers. Journal of Language Teaching and Research, 6(5), 976-984.

Al-Ghamdi, E. (2013). The length-of-residence effect on apology strategies: A comparison of Saudis apology strategies in Arabic and in English as a foreign language, (Unpublished Master's thesis). Manchester Metropolitan University, Manchester, England.

Al-Kharrat, M. Y. (2000). Deductive \& inductive lessons for Saudi EFL freshmen students. The Internet TESL Journal, 6(10). http://iteslj.org/Techniques/Al-Kharrat-Deductive/ 
Arab World English Journal (AWEJ) Volume 12. Number 1. March 2021

The Effect of Explicit Instruction of Requests on Saudi EFL learners

Qari

Al-Otaibi, S. (2015). Saudi EFL Students' Knowledge in Pragmatics - Making Requests. Arab World English Journal, 6(2), 302-315. doi:10.24093/awej/vol6no2.23

Alhudhaif, A. M. (2000). Length of residence and pragmatic knowledge of Saudi learners of American English: The case of apology, (Unpublished Doctoral dissertation). Colorado State University, Colorado.

Alkahtani, S. A. (2012). Request strategies by second language learners of English: Pre-and post-head act strategies. Studies in Literature and Language, 5(2), 16-28.

Alraddadi, B. (2019). An Analysis of the Effects of Explicit Teaching on the Acquisition of Structural Discourse Markers in EFL Speaking Classes in Saudi Arabia, (Unpublished Doctoral dissertation) University of Central Lancashire, Preston, Lancashire, England.

Alsmari, N. A. (2020). A Video-driven Approach to Promoting Pragmatic Development in the Context of English as a Foreign Language. Arab World English Journal, (6), 3-23. DOI: https://dx.doi.org/10.24093/awej/call6.1

Alsuhaibani, Z. (2020). Developing EFL students' pragmatic competence: The case of compliment responses. Language Teaching Research, 333-342. https://doi.org/10.1177/1362168820913539

Anani Sarab, M. R., \& Alikhani, S. (2015). Pragmatics instruction in EFL context: A focus on requests. International Journal of Research Studies in Language Learning, 5(1), 29-42.

Batawi, G. H. (2006). Exploring the use of CLT in Saudi Arabia, (Unpublished Master's thesis). American University of Sharjah, UAE.

Blum-Kulka, S., \& Olshtain, E. (1984). Requests and apologies: A cross-cultural study of speech act realization patterns (CCSARP). Applied linguistics, 5(3), 196-213. https://doi.org/10.1093/applin/5.3.196

El-Dakhs, D. A. S. (2018). Investigating the apology strategies of Saudi learners of English: Foreign language learning in focus. Pragmatics and Society, 9(4), 598-625. https://doi.org/10.1075/ps.16048.eld

Ellis, R. (1994). The study of second language acquisition. Oxford, Oxford University Press.

Eslami-Rasekh, Z., Eslami-Rasekh, A., \& Fatahi, A. (2004). The Effect of Explicit Metapragmatic Instruction on the Speech Act Awareness of Advanced EFL Students. TESL-EJ, 8(2). https://files.eric.ed.gov/fulltext/EJ1068089.pdf

Eslami-Rasekh, Z. (2005). Raising the pragmatic awareness of language learners. ELT journal, 59(3), 199208. doi:10.1093/elt/cci039.

Farahian, M., Rezaee, M., \& Gholami, A. (2012). Does direct instruction develop pragmatic competence? Teaching refusals to EFL learners of English. Journal of Language Teaching and Research, 3(4), 814-821. doi:10.4304/jltr.3.4.814-821

Fattah, S. (2018). Role-play as an independent learning technique in developing semantic \& pragmatic competence. Annals of Language and Literature, 2(1), 27-32.

Glaser, K. (2014). The Neglected Combination: A Case for Explicit-Inductive Instruction in Teaching Pragmatics in ESL. TESL Canada Journal, 30(Special Issue 7), 150-163.

$\mathrm{Gu}, \mathrm{X}$. (2011). The Effect of Explicit and Implicit Instructions of Request Strategies. Intercultural Communication Studies, 20(1), 104-123.

Halenko, N., \& Jones, C. (2011). Teaching pragmatic awareness of spoken requests to Chinese EAP learners in the UK: Is explicit instruction effective? System, 39(2), 240-250. DOI: 10.1016/j.system.2011.05.003

Hintzman, D. L., \& Block, R. A. (1971). Repetition and memory: Evidence for a multiple-trace hypothesis. Journal of Experimental Psychology, 88(3), 297-306. https://doi.org/10.1037/h0030907 
Arab World English Journal (AWEJ) Volume 12. Number 1. March 2021

The Effect of Explicit Instruction of Requests on Saudi EFL learners

Qari

Kerber, N. K. (2020). Second Language Acquisition: The Need for Explicit Pragmatic Instruction in Beginning-level Language Classes, (Unpublished Doctoral dissertation). Baylor University, Texas.

Khodareza, M., \& Lotfi, A. (2013). Interlanguage pragmatic development: The effect of formal instruction on Iranian EFL learners' interpretation and use of speech act of apology. Asian Journal of Social Sciences and Humanities, 2(2), 99-104.

Nguyen, T. T. M., Pham, T. H., \& Pham, M. T. (2012). The relative effects of explicit and implicit formfocused instruction on the development of L2 pragmatic competence. Journal of pragmatics, 44(4), 416-434.

Plonsky, L., \& Zhuang, J. (2019). A meta-analysis of L2 pragmatics instruction: The Routledge handbook of SLA and pragmatics. New York: Routledge. https://doi. org/10.4324/9781351164085-19.

Qari, I. (2017). Politeness study of requests and apologies as produced by Saudi Hijazi, EFL learners, and British English university students, (Unpublished Doctoral dissertation) University of Roehampton, London, U.K.

Rafieyan, V., Sharafi-Nejad, M., \& Eng, L. S. (2014). Effect of pragmatic instruction on sustainable development of pragmatic awareness. Journal of Studies in Education, 4(1), 206-218.

Rajabia, S., Azizifara, A., \& Gowhary, H. (2015). The effect of explicit instruction on pragmatic competence development; teaching requests to EFL learners of English. Procedia-Social and Behavioral Sciences, 199(3), 231-239. DOI: 10.1016/j.sbspro.2015.07.511

Rueda, Y. (2006). Developing pragmatic competence in a foreign language. Colombian applied linguistics journal, (8), 169-182.

Schmidt, R. (1990). The role of consciousness in second language learning1. Applied linguistics, 11(2), 129-158. https://doi.org/10.1093/applin/11.2.129

Schmidt, R. (2001). Attention. In P. Robinson (Ed.), Cognition and Second Language Instruction (pp. 332). Cambridge: Cambridge University Press.

Schmidt, R. (2012). Attention, awareness, and individual differences in language learning. In W. M. Chan, K. N. Chin, S. Bhatt \& I. Walker (Eds.), perspectives on individual characteristics and foreign language education (pp. 27-50). Walter de Gruyter

Searle, J. R. (1969). Speech acts: An essay in the philosophy of language (Vol. 626). Cambridge, Cambridge university press.

Shark, P. (2019). The Effects of Explicit/Implicit Instructions on the Development of Advanced EFL Learners' Pragmatic Knowledge of English: Apology Speech Act. Journal of Language Teaching \& Research, 10(1), 76-82.

Selinker, L. (2014). Interlanguage 40 years on: Three themes from here. In Z. Han, \& E. Tarone (Eds.), Interlanguage Forty years later (pp. 221-246). Amsterdam and Philadelphia: John Benjamins Publishing.

Shokouhi, S. (2016). An Overview on Explicit and Implicit instructions on Learners' Pragmatic Awareness in Making Request in English. Journal for the Study of English Linguistics,4(1), 60-69.

Tawalbeh, A., \& Al-Oqaily, E. (2012). In-directness and politeness in American English and Saudi Arabic requests: A cross-cultural comparison. Asian Social Science, 8(10), $85 . \quad$ DOI: 10.5539/ass.v8n10p85

Thomas, J. (1983). Cross-cultural pragmatic failure. Applied linguistics, 4(2), 91-112. https://doi.org/10.1093/applin/4.2.91

Vellenga, H. (2004). Learning Pragmatics from ESL \& EFL Textbooks: How Likely?. Tesl-Ej, 8(2), 25-38.

Yilmaz, N., \& Koc, D. K. (2020). Developing pragmatic comprehension and production: Corpus-based teaching of formulaic sequences in an EFL setting. Journal of Language and Linguistic Studies, 16(1), 474-488.

Arab World English Journal 